Editorial

\title{
The Politics and Aesthetics of the Urban Commons: Navigating the Gaze of the City, the State, the Market
}

\author{
Louis Volont ${ }^{1}$ and Peer Smets ${ }^{2, *}$ \\ ${ }^{1}$ Massachusetts Institute of Technology (MIT), School of Architecture + Planning, USA \\ 2 Department of Sociology, Vrije Universiteit Amsterdam, The Netherlands \\ * Corresponding author (p.g.s.m.smets@vu.nl)
}

Submitted: 2 February 2022 | Published: 22 February 2022

\begin{abstract}
This thematic issue puts "urban commoning" centre stage. Urban commoning constitutes the practice of sharing urban resources (space, streets, energy, and more) through principles of inclusion and cooperation. Whilst generally defined as an autonomous, bottom-up, and most of all cooperative practice, the sphere of the commons necessarily stands in interaction with two other spheres: the state/city ("provision") and the market ("competition"). Yet, the various interlinkages between the commons, the state/city, and the market are underexplored. Hence the rationale for this thematic issue: How does the relation between commons, states/cities, and markets play out in the urban realm? What are the possibilities and pitfalls of linking commons with states/cities and markets? In the first section of this editorial, we provide a substantiated introduction to the concept of the commons, its history, and its urban applications. In the second part, we give an overview of the issue's contributions. Scholars, activists, and practitioners from the disciplines of urban studies, cultural studies, planning, sustainability, sociology, architecture, and philosophy delve into the uncharted territory between commons, states/cities, and markets, through case studies from the Global North and South. The first three articles delve into the politics of urban commoning while the last three articles illuminate the practice's aesthetic dimension.
\end{abstract}

\section{Keywords}

city; commoning; commons; market; neoliberalism; space; state

\section{Issue}

This editorial is a part of the issue "The Politics and Aesthetics of the Urban Commons: Navigating the Gaze of the City, the State, the Market" edited by Peer Smets (Vrije Universiteit Amsterdam) and Louis Volont (Massachusetts Institute of Technology).

(C) 2022 by the author(s); licensee Cogitatio (Lisbon, Portugal). This editorial is licensed under a Creative Commons Attribution 4.0 International License (CC BY).

\section{Introduction}

This thematic issue brings the practice of urban commoning into dialogue with two other social spheres: the state/city and the market. How do the commons ("cooperation"), states/cities ("provision") and markets ("competition") entangle and interact? What are the possibilities and pitfalls of these interlinkages, specifically in the urban realm? In this editorial, we will (a) disentangle the theoretical underpinnings of urban commoning and (b) give an overview of the articles published in this edition.
It is safe to say that the city has become a pivotal place in which global challenges unfold: climate change, housing inequality, privatization of public services, political conflict, gentrification, poverty, stress, pandemics, to name just a few. Yet, one may wonder whether Simmel (1903/2005) was right in saying that the urban experience turns the urbanite into a "blasé," uncaring, disinterested social subject. After all, the city also constitutes the battlefield on which the aforementioned challenges are confronted by groups as diverse as citizens, activists, artists, and policy representatives. Through for example autonomous neighbourhoods, 
urban occupations, Community Land Trusts, and grassroots artistic experimentation, urbanites in the Global North and South set out to reassert participatory control over the urban commonwealth.

"A commons" refers to a resource shared by a group of people (Ostrom, 1990). "Commoning," then, constitutes the everyday practice of sharing resources, a cooperative stance that goes beyond state/public provision and market-based competition. The "commoner," finally, is the social subject engaging in the sharing, based on principles of inclusivity and cooperation.

Commoning dates back to the feudal mode of social organization, flourishing in Europe between the 9th and 15th centuries. In that constellation, the commons were unparcelled pieces of rural land, collectively cultivated and relied upon by peasant families (Bravo \& De Moor, 2008; Zückert, 2012). For the landless masses and disparate groups of tradesmen, artisans, and immigrants, survival depended entirely on natural common resources as a means of subsistence, a dependence which was enabled by customary law or outright trespass (Linebaugh, 2008, 2014).

With this thematic issue, however, we investigate commoning in current times and in urban conditions. As Kip (2015) once argued: "The commons thus finally come to town." For our present purposes, we consider the work of American economist Elinor Ostrom as the first significant academic interest in modern commoning. Ostrom (1990) set out to lay bare the organizational preconditions that would allow for sustainable commoning. In her landmark study Governing the Commons, she defined a series of organizational "design principles" for sustainable and collective resource managementdefining clear group boundaries, matching the rules of resource use to local conditions, ensuring that fellowcommoners can participate in modifying the rules, developing a system for monitoring fellow-commoners' behaviour, deploying sanctions for rule violators, providing accessible and low-cost means of dispute resolution, and having one's commoning project recognized ("not challenged") by external governmental authorities.

Whilst Ostrom's account was based on environmental commons (water basins, forests, irrigation systems), it was her colleague Charlotte Hess who shifted the focus to "various types of shared resources that have recently evolved.... without pre-existing rules or clear institutional arrangements" (Hess, 2008, p. 1), such as "cultural commons," "knowledge commons," "infrastructure commons," and "neighbourhood commons" (see also Hess \& Ostrom, 2007).

Moreover, Ostrom's precedent has inspired a new wave of urban literature (Foster \& laione, 2016; laione, $2015,2016)$ that conceives of urban commoning as the process whereby the governance of urban spaces (parks, streets, deserted factories, and the like) is devolved from the municipality to the urban citizenry. Examples can be found in the Bologna Regulation for the Care and Regeneration of Urban Commons, in the civic manage- ment facilities discussed by Pera and Bianchi (2022), and in the environmentally-oriented urban commons discussed by Colding et al. (2022).

In recent years, an emancipatory school of thought has seen the light of day as well, in which urban commoning is explicitly conceived as a bottom-up political project against the reign of capital in the urban realm. Hardt and Negri (2009), for instance, have coined the notion of "the common," referring not only to "the fruits of the soil" and to "nature's bounty," but more so to the shared outcomes of urban sociality ("social production"). By being together and co-mingling in the city, Hardt and Negri argue, urbanites create vibes, moods, languages, cultures, affects-in all: common goods which are invariably prone to privatization. As Hardt and Negri (2009, p. 142) wrote in Commonwealth, "capital simply [hovers] over [the common] parasitically with its disciplinary regimes, apparatuses of capture, mechanisms of appropriation, financial networks and the like."

In a similar vein, Stavrides (2012, p. 588) put forward the concept of "common space," which:

Is not the public space as we know it, space given from a certain authority to the public...nor is it private space, if by this we mean space controlled and used by a limited group of people....Communities create "common space," space used under conditions decided on by communities and open to anyone.

Hence, the here-described emancipatory school emphasizes that the urban commons are not just mere resources to be shared, but also, and more importantly, a "means" through which to explore new and emancipatory forms of togetherness in the contemporary city. This school inherently argues that urban commons are not evidently pre-given, but must be made "common" by the social subject of the commoner and through the very process of commoning. "Commoning," De Angelis (2017, p. 211) contends, "is a form of social cooperation...that operates outside the code and protocol of capitalist-dominated social cooperation...in which profit for profit's sake, expropriation and competitiveness are not the dominant drivers."

The previous discussion of the Ostromian and the emancipatory tradition in (urban) commons scholarship is inevitably a reductive one. Far more theoretical accounts and empirical applications can be found in an extensive body of commons literature (Bresnihan \& Byrne, 2015; Dardot \& Laval, 2019; Eizenberg, 2012; Harvey, 2011; Noterman, 2016; Volont \& Dobson, 2021). However, one finding invariably recurs throughout the field. The sphere of the commons necessarily stands in interaction with two other spheres: the state/city and the market. It is our contention that the various interlinkages between the commons, the state/city, and the market are not well-understood and are undertheorized. Hence the rationale for this thematic issue: How does the relation between commons, states/cities, and markets 
play out in the urban realm? Which forms can these interlinkages take on? What are the possibilities and pitfalls of linking commons with states/cities and markets?

An additional rationale for our endeavour is the observation that both the state/city and the marketessential foundations of social life-are dominated by neoliberal values. Neoliberal values have created models that encourage individualism and discourage cooperation. The state tends to stimulate competition and individual conduct, which has led to a number of financial, economic, and social crises (Beck, 1992; Bollier, 2014; Geldof, 2020; Smets \& Salman, 2008). Overall, we may describe the neoliberal state by a transition from "government" to "governance." Governmental institutions set up partnerships with actors from the market and/or civil society. These partnerships could offer possibilities for innovation but are also pervaded by market principles, privatization, the growth of private sector organizations, and non-bureaucratic modes of regulation (Peck et al., 2009). It is important to mention that the impact of neoliberalism differs in different countries. For example, England deals with a strict form of neoliberalism where the government has a small role, while the Netherlands cope with a neoliberal approach in which the governmental bureaucracy dominates (Korstenbroek \& Smets, 2019).

Hence, homo economicus plays a prominent role in the market where efficiency reigns supreme. Enterprises often influence the state by using powerful political lobbies, interest groups, and institutionalized politics. Their aim is market exchange and growth in such a way that profit will be dominant. As such, scarcity can be used to raise profit margins. Neoliberalism brings together capitalism and democracy, which generates friction between market solutions and local empowerment.
In other words, neoliberalism hampers democratic planning (Goonewardena, 2003). One example is the deliberative co-optation of protestors, once they will be faced with repeated cycles of institutional practices and authority discourses (Sager, 2011). Another example is what De Angelis (2013, p. 605-606) calls the "commons fix," i.e., the process whereby markets, states, and municipalities, guided by the reign of capital, "have to ask the commons to help manage the devastation."

However, once stakeholders from the commons, the state/city, and the market find a common ground, it creates possibilities for the creation of vital coalitions. Stakeholders working together with the local government can create ad-hoc and sustainable actions. Governance creates cooperation among stakeholders but also enables opportunities for power games among the elites who tend to decide what is useful for the other partners (Swyngedouw, 2005). The different groups have to face frictions between the mindsets of the partners within the triarchy. Governments tend to use a SMART approach that goes together with blueprints. The market and the commons tend to use a more flexible process approach (Smets \& Azarhoosh, 2019).

Given this thematic issue's focus on the interplay between the commons, the state/city, and the market, we end this introductory section with Table 1, which gives an overview of the essential characteristics of the issue's central tripartite.

\section{Overview of the Articles}

Each article in this thematic issue illuminates the interrelationship between the three essential realms - the commons, the state/city, the market-in its own distinctive way. Nevertheless, as the issue's overall title attests, we

Table 1. A short comparison of the market, the state, and the commons.

\begin{tabular}{llll}
\hline & Market & State & Commons \\
\hline Resources & Scarcity is given or created & Public funds & For rivalrous resources, there is enough \\
& & for all through sharing. For non-rivalrous \\
& & resources there is abundance
\end{tabular}

$\begin{array}{lll}\text { Strategy } & \text { Efficient resource allocation } & \text { Effective approach } \\ \begin{array}{l}\text { Ideas of } \\ \text { individual }\end{array} & \text { Homo economicus } & \text { Equality for all } \\ \text { Change agents } & \begin{array}{l}\text { Powerful political lobbies, interest } \\ \text { groups, and institutionalized } \\ \text { politics focused on government }\end{array} & \text { Law and policies }\end{array}$
Focus
Market exchange and growth through individual initiative, innovation and efficiency

Core question What can be sold and bought?
Rules, regulations

How can citizens be treated equally

\section{Strengthening social relations}

Humans are primarily cooperative social beings

Diverse communities working as diversity networks, with solutions coming from the margins

Use-value, common wealth, sustainable livelihoods and complementarity of enterprise

What do l/we need to live?

Source: Based on Bollier (2014, p. 179) and Bauwens (2010). 
present two clusters consisting of three articles each: the first cluster evolves around the politics of the urban commons; the second one around the aesthetics of the urban commons.

We open the first cluster with Caroline Newton and Roberto Rocco's article "Actually Existing Commons: Using the Commons to Reclaim the City." The authors advocate a conception of urban commoning that goes beyond the traditional imaginary of inclusivity, horizontal organization, and anti-capitalism. Instead, they shift the focus to the role of local communities, everyday commoning, and power mechanisms in slum governance. Newton and Rocco take us to the Paraisópolis slum in São Paulo, Brazil, where community development reflects the reproduction of social life in combination with everyday realities. At Paraisópolis, many communities and processes of commoning are widespread. The authors immediately touch upon the essence of the thematic issue, arguing that "rather than being purely insurgent against the market and the state, the commons exist in a complex web of continuous negotiation and trade-offs with them" (Newton \& Rocco, 2022, p. 92). We discover how commoning practices are intertwined with the Covid-19 pandemic and at certain moments proved to be more successful than outside the slum area. In Newton and Rocco's account, slum dwellers are neither "victims" nor "heroes" but commoners: The slum commons create opportunities for citizens in vulnerable circumstances as they make use of formal and informal institutions of the state/city and the market. In fact, the slum contains a web of "nested commons," in which communities, state/city, and market interact through dialogue or struggle to obtain access to resources (water, electricity, land) and facilities (such as health care).

The cluster continues with the article "Urban Commons and Collective Action to Address Climate Change," by Johan Colding, Stephan Barthel, Robert Ljung, Felix Eriksson, and Stefan Sjöberg. This article evolves around collective action against the climate crisis: urban green commons, co-working spaces, and community climate commons. Urban green commons include for example allotments and community gardens that encourage environmental learning about global warming and its consequences. Co-working spaces create opportunities for sharing institutional attributes of commons by for example the sharing economy and through the reduction of transport and commuting distance. Thirdly, community climate commons create possibilities for reducing the use of carbon and for empowering communities and civil society groups. The authors also explore the determinants for the up-scaling of environmentally-oriented urban commons in a critical manner. Colding et al. (2022) argue for public sector support, but doubt whether private interests could or should sustain the development of urban commons. Moreover, collective choice arrangements in co-working spaces emerge as desirable, but it remains to be discovered how the continuum between "privately-run" and "collectively-run" manifests itself in the empirical realm. And lastly-scale. Colding and colleagues argue that trust-building is an essential characteristic of wellfunctioning common property systems. Smaller groups are likely to sustain trust and social cohesion. Once communities become too large or the number of stakeholders grows too much, trust among participants decreases; as seen earlier, this is a distinctively Ostromian statement. Overall: small is beautiful.

We end the first cluster with Marina Pera and Iolanda Bianchi's article "Governmentality, the Local State, and the Commons: An Analysis of Civic Management Facilities in Barcelona." Civic management facilities (cultural centres, neighbourhood centres, youth centres, among others) are in the hands of the City of Barcelona, but their operation and maintenance are in the hands of the communities that establish their own rules and norms to carry out socially transformative projects. We thus encounter commoning practices that are characterized by a hybrid institutional configuration. Building on Foucault's notion of governmentality, Pera and Bianchi (2022) show how the municipality uses technologies of power to control administration and bureaucratic procedures which encapsulates elements of revisionist neoliberalism. Such development tends to neutralize transformation and depoliticize the community that manages the facilities. Still, both realms (city, community) benefit from this hybrid form. For the commons, it creates opportunities for stability and economic capacity; for the local government, it creates opportunities for service provision and citizen participation. Reminiscent of the arguments made by Newton and Rocco (2022), these authors reiterate that purely autonomist commons are hard to find; or, in the words of the authors, that "it is rarely possible for commons to achieve autonomy in capitalist societies" (Pera \& Bianchi, 2022, p. 122).

In the second cluster, we group three articles that revolve around the aesthetics of urban commoning. The cluster opens with Bart Wissink and Lara van Meeteren's article “Art Organisers as Commoners: On the Sustainability and Counter-Hegemonic Potential of the Bangkok Biennial." In this article, we discover how the relationship between commons, state and market is played out in the field of cultural production. Wissink and van Meeteren (2022) provide a detailed account of the commons-based Bangkok Biennial. The authors reflect on the counter-hegemonic potency of the latter, particularly in relation to the state-organized Thailand Biennale and the corporate Bangkok Art Biennale. Playing a pivotal part in this contribution is political philosopher Chantal Mouffe's conceptual apparatus. Mouffe is known for her argument that "politics proper" implies a perpetual clash between hegemonic projects in all domains of society; in the grander scheme of this issue, this would mean an engagement of the commons with the state/city and the market. However, Wissink and van Meeteren posit an important caveat: context is crucial. The commons- 
based Bangkok Biennial explicitly refused to engage with state and market actors, thus embarking on what may be called an "exodus" strategy. As the authors argue, the commoners involved imagined "state and market parties not as friendly opposition, but as enemies with whom they shouldn't engage" (Wissink \& van Meeteren, 2022, p. 137). Whilst the exodus approach might undermine the sustainability of commoning practices, the authors end their article nevertheless with a reflection on how artists might take on organizing functions, in the streets as well as in the art world. Such multiplicity of organizing roles, the authors argue, is what might augment the sustainability of counter-hegemonic artistic commoning.

The cluster continues with Louis Volont's "Urban Commoning: An Assessment of Its Aesthetic Dimension." Volont approaches the notion of "aesthetics" in the literal sense, namely, as "that which presents itself to sense perception" (Volont, 2022, p. 141). Urban politics, Volont argues with the help of philosopher Jacques Rancière, is a constant play of aesthetics: Some social groups are seen and heard, whilst others pass unnoticed. Some have a voice, others are noise. The article describes the case of Pension Almonde, Rotterdam. Pension Almonde emerged after a group of commoners transformed a vacant social housing complex into a temporary living and working space for individuals and cultural initiatives who, due to the nomadic nature of their activities, are unable to apply for social housing, nor to buy accommodation on the private market. The aim of Pension Almonde was thus an inherently aesthetic one: to make the voice of nomadic urbanites perceptible in Rotterdam's urban public realm. Through a thick description of the social dynamics unfolding at Pension Almonde, Volont highlights how the project made the voice of urban nomads and cultural initiatives perceptible in the urban arena but simultaneously struggled to shift political power differentials in relation to the property owner of the social housing complex. Volont, therefore, argues to move away from active, "artificialized," community formation as was seen in Rotterdam, and proposes instead "let commoning communities emerge autonomously" (p. 150). Lastly, the author maintains that the shifting of power relations becomes possible only when activists "consider a given project's universal relevance (equality, humanity, inclusion) rather than its technical utility" (p. 150). For this, he argues pro an agonistic relation between the commons, the state, and the market.

We end the thematic issue with Thijs Lijster's "Community, Commons, Common Sense." Lijster's contribution is broad in theoretical scope, yet specific in analytical focus. It has become a truism to state that there are no commons without community. However, Lijster asks, what kind of community should that be? In everyday politics and parlance, the notion of community continues to be equated with static unities, bound to specific territories or ethnicities. Lijster shows how current commons scholarship has tried to overturn such identitarian conception of community, by framing the commoning community as an "organizational principle" (De Angelis, 2017) or as the cause and consequence of collective praxis (Dardot \& Laval, 2019). Yet Lijster is not content with this solution and argues that current commons scholarship largely overlooks the cultural and symbolic connotations of the concept of community. To solve the impasse, Lijster finds refuge in Kant and Rancière to present a fresh conception of community. Lijster's (2022, p. 158) community is grounded in joint action but is "not restricted by it, being sufficiently open to be imagined otherwise." Lijster's commoning community is furthermore pervaded by what he calls a dissensual commonsense, "wherein common sense refers to how we commonly sense the world, and to the way we conceive of ourselves as community" (p. 158). Citing urban examples from Greece and the Netherlands, Lijster explores the consequences of his account and concludes the issue with a significant statement:

The question of whether we see (sense) and understand (make sense of) something as either "common" or as "commodity" has drastic consequences for our world, and will make the difference between a politics of extraction, exploitation, and inequality, or one of common abundance, mutual care, and democratic governance.

\section{Acknowledgments}

We wish to thank each and every contributing author, for their willingness to compose this issue with us and their continued enthusiasm to deliver quality scholarly work on urban commoning. In addition, a word of gratitude must necessarily go to the different case studies (their participants, commoners, organizers, activists, artists) that have made the writing of the articles, and by extension this thematic issue, possible. Lastly, a final word of thanks goes to the collaborators and editors at Social Inclusion, who have assured a smooth production of the issue, from the early stages until final publication.

\section{References}

Bauwens, M. (2010). The new triarchy: The commons, enterprise, the state. P2P Foundation.

Beck, U. (1992). From industrial society to the risk society: Questions of survival, social structure and ecological enlightenment. Theory, Culture \& Society, 9(1), 97-123.

Bollier, D. (2014). Think like a commoner: A short introduction to the life of the commons. New Society Publishers.

Bravo, G., \& De Moor, T. (2008). The commons in Europe: From past to future. International Journal of the Commons, 2(2), 155-161.

Bresnihan, P., \& Byrne, M. (2015). Escape into the city: Everyday practices of commoning and the produc- 
tion of urban space in Dublin. Antipode, 47(1), 36-54.

Colding, J., Barthel, S., Ljung, R., Eriksson, F., \& Sjöberg,

S. (2022). Urban commons and collective action to address climate change. Social Inclusion, 10(1), 103-114.

Dardot, P., \& Laval, C. (2019). Common: On revolution in the 21st century. Bloomsbury Academic.

De Angelis, M. (2013). Does capital need a commons fix? Ephemera: Theory \& Politics in Organization, 13(3), 603-615.

De Angelis, M. (2017). Omnia sunt communia: On the commons and the transformation to postcapitalism. Zed Books.

Eizenberg, E. (2012). Actually existing commons: Three moments of space of community gardens in New York City. Antipode, 44(3), 764-782.

Foster, S., \& laione, C. (2016). The city as a commons. Yale Law \& Policy Review, 34(2), 281-349.

Geldof, D. (2020). Als Risico's Viraal Gaan: Welke Wereld na Corona? [If risks go viral: Which world after Corona?] Acco.

Goonewardena, K. (2003). The future of planning at the "end of history." Planning Theory, 2(3), 183-224.

Hardt, M., \& Negri, A. (2009). Commonwealth. Harvard University Press.

Harvey, D. (2011). The future of the commons. Radical History Review, 2011(109), 101-107.

Hess, C. (2008). Mapping the new commons [Paper presentation]. The 12th Biennial Conference of the International Association for the Study of the Commons, Cheltenham, UK.

Hess, C., \& Ostrom, E. (2007). Introduction: An overview of the Knowledge commons. In C. Hess \& E. Ostrom (Eds.), Understanding knowledge as a commons: From theory to practice (pp. 3-26). MIT Press.

laione, C. (2015). Governing the urban commons. Italian Journal of Public Law, 7(1), 170-221.

laione, C. (2016). The CO-City: Sharing, collaborating, cooperating, and commoning in the city. American Journal of Economics and Sociology, 75(2), 415-455.

Kip, M. (2015). Moving beyond the city: Conceptualizing urban commons from a critical urban studies perspective. In M. Dellenbaugh, M. Kip, M. Bieniok, A. Müller, \& M. Schwegmann (Eds.), Urban commons: Moving beyond state and market (pp. 42-59). Birkhäuser.

Korstenbroek, T., \& Smets, P. (2019). Developing the potential for change: Challenging power through social entrepreneurship in the Netherlands. VOLUNTAS: International Journal of Voluntary and Nonprofit Organizations, 30(3), 475-486.

Lijster, T. (2022). Community, commons, common sense. Social Inclusion, 10(1), 152-160.
Linebaugh, P. (2008). The Magna Carta manifesto: Liberties and commons for all. University of California Press.

Linebaugh, P. (2014). Stop, thief! The commons, enclosures, and resistance. PM Press.

Newton, C., \& Rocco, R. (2022). Actually existing commons: Using the commons to reclaim the city. Social Inclusion, 10(1), 91-102.

Noterman, E. (2016). Beyond tragedy: Differential commoning in a manufactured housing cooperative. Antipode, 48(2), 433-452.

Ostrom, E. (1990). Governing the commons: The evolution of institutions for collective action. Cambridge University Press.

Peck, J., Theodore, N., \& Brenner, N. (2009). Neoliberal urbanism: Models, moments, mutations. SAIS Review of International Affairs, 29(1), 49-66.

Pera, M., \& Bianchi, I. (2022). Governmentality, the local state, and the commons: An analysis of civic management facilities in Barcelona. Social Inclusion, 10(1), 115-125.

Sager, T. (2011). Neo-liberal urban planning policies: A literature survey 1990-2010. Progress in Planning, 76, 147-199.

Simmel, G. (2005). The metropolis and mental life. In J. Lin \& S. Mele (Eds.), The urban sociology reader (pp. 23-31). Routledge. (Original work published 1903)

Smets, P., \& Azarhoosh, F. (2019). Urban commons and commoning in Amsterdam East: The role of liquid communities and the local government. Sociologia e Politiche Sociali, 22(1), 91-109.

Smets, P., \& Salman, T. (2008). Countering urban segregation: Theoretical and policy innovations from around the globe. Urban Studies, 45(7), 1307-1332.

Stavrides, S. (2012). Squares in movement. South Atlantic Quarterly, 111(3), 585-596.

Swyngedouw, E. (2005). Governance innovation and the citizen: The Janus Face of governance-beyond-thestate. Urban Studies, 42(11), 1991-2006.

Volont, L. (2022). Urban commoning: An assessment of its aesthetic dimension. Social Inclusion, 10(1), 141-151.

Volont, L., \& Dobson, T. (2021). The political intricacies of common space: A Rancièrian approach to the "public land grab," London. Antipode, 53(6), 1853-1872.

Wissink, B., \& van Meeteren, L. (2022). Art organisers as commoners: On the sustainability and counter-hegemonic potential of the Bangkok Biennial. Social Inclusion, 10(1), 126-140.

Zückert, H. (2012). The commons: A historical concept of property rights. In D. Bollier \& S. Helfrich (Eds.), The wealth of the commons: A world beyond market \& state (pp. 121-135). Levellers Press. 


\section{COGITATIO}

\section{About the Authors}

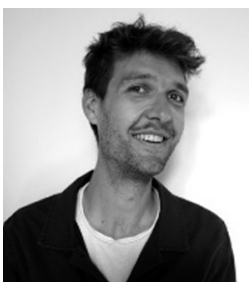

Louis Volont is a sociologist who works at the crossroads of urban and theoretical sociology. He is currently a post-doctoral visiting scholar at MIT's School of Architecture + Planning, in the Art, Culture \& Technology program (ACT). His research interests are the production of urban space, the work of Henri Lefebvre, urban commoning, socio-technical imaginaries, and urban adaptation to climate change.

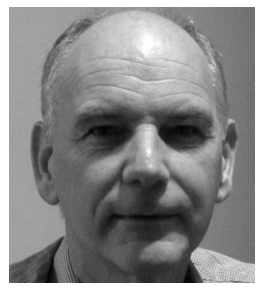

Peer Smets (PhD) is a senior researcher in the Department of Sociology at the Vrije Universiteit Amsterdam. His research interest is in urban studies and neighbourhood development with a focus on physical and social-cultural elements. Moreover, he looks into people living in vulnerable circumstances and coping strategies. His publications include many articles and co-edited special journal issues and books. 